\title{
Survey on composition of perennial vegetation in Sesa Mariam Monastery, Northwestern Ethiopia
}

\author{
Birhanu Woldie Meshesha', Berhanu Abraha Tsegay ${ }^{2 *}$ and Birhanu Belay Telake ${ }^{3}$
}

\begin{abstract}
Background: Sustainable use of natural resources is one of the leading agenda because anthropogenic activities are leading to the depletion of these resources. Ethiopia is one of the biodiversity reach areas in the world, but the floral diversity is being threatened before they are fully explored. In line with this, very little is known about the flora of Sesa Mariam monastery, found in northwest Ethiopia. The area is one of the few remnant monastery forests in the country with old aged tree species. The aim of the study was to explore and document the floristic composition, density and regeneration status of perennial plant species in order to provide base line information for the sustainable utilization and management of the forest resources.
\end{abstract}

Methodology: Fifty-one (51) quadrats ( $20 \mathrm{~m} \times 20 \mathrm{~m}$ each) were laid along established transect lines for census of perennial plant species. Two nested quadrats $(2 \mathrm{~m} \times 10 \mathrm{~m})$ were also used at the beginning and at the end of every main quadrat for the assessment of seedlings and saplings. All woody plant species in each quadrat were counted and identified. Species diversity, richness and evenness were measured.

Results: One hundred and thirteen (113) plant species belonging to 89 genera and 54 families were identified. Moreover, there were 7 more species outside the study quadrats. Of these plant species 10 were endemic, 92 were indigenous, and the remaining 11 were exotic cultivated trees and shrubs. Fabaceae is the most dominant family with 14 species followed by Euphorbiaceae and Rutaceae, each with 6 species. The total basal area of the matured woody plants of the forest was $94.81 \mathrm{~m}^{2} \mathrm{ha}^{-1}$ and the density was 1960.78 individuals ha ${ }^{-1}$. The overall diversity and evenness of woody species were 3.81 and 0.85 , respectively. When compared to other forests found in Ethiopia, it is better protected.

Conclusion: The data from this study showed a relatively good conservation status. However, analysis from individual woody plant structure, and count of seedlings and saplings showed a need for conservation. Stopping or minimizing grazing by livestock and selective tree cuttings are the first measures to be taken for conservation.

Keywords: Diversity, Evenness, Density, Regeneration status, Basal area

\section{Background}

The flora of Ethiopia is very heterogeneous and it is estimated to contain around 6500-7000 species of higher plants, of which about $12-19 \%$ are endemic [1-4]. This rich diversity and endemism of the country is mainly related with the presence of its diverse ecological

\footnotetext{
*Correspondence: berhanu.tsegay@gmail.com

2 Department of Biology, Bahir Dar University, Bahir Dar, Ethiopia

Full list of author information is available at the end of the article
}

features. However, different studies confirmed that all the natural vegetation types of Ethiopia are under harsh threats [5, 6]. According to Alemayehu [7], the speedy depletion of forest resources in Ethiopia has brought significant decline in their biodiversity to the extent that some species are on the verge of local extinction. Because of the early human settlement accompanied by rudimentary farming techniques, extensive cattle husbandry, and ever-increasing human and livestock populations, the rate of deforestation is exceptionally aggravated in the 
northern Ethiopian highlands [7]. In such devastated areas, conserving and safeguarding of plant diversity has been a very challenging task. Some of the remaining forest patches of Ethiopia are located in the vicinities of churches and monasteries under the protection of the Ethiopian Orthodox Tewahdo Church (EOTC). The EOTC has a long history of planting, protecting and conserving trees. Thus, churches and monasteries are not only considered as religious spots but also as biodiversity hotspot areas.

Sesa Mariam Monastery Forest (SMMF) is one of the remnant forest patches found in northwestern Ethiopia. The dominant plant species of SMMF are more related to Dry Evergreen Montane Forest and recently it was designated as part of the Eastern Afromontane biodiversity hotspots, which made Afromontane rain forests of Ethiopia as one of the 34 hotspot areas in the world [8]. This part of the Afromontane forest is being severely threatened by anthropogenic factors. Therefore, this study was conducted to explore and document the floristic composition, density and regeneration status of the monastery in order to provide base line information for the sustainable utilization and management of the forest resources.

\section{Methods}

\section{Study area}

Sesa Mariam Monastery is found in Gozamin district (locally called Woreda), Northwest Ethiopia. It is located between $10^{\circ} 14^{\prime} 34^{\prime \prime} \mathrm{N}-10^{\circ} 14^{\prime} 53^{\prime \prime} \mathrm{N}$ latitudes and $37^{\circ} 39^{\prime} \mathrm{E}-37^{\circ} 40^{\prime} \mathrm{E}$ longitudes (Fig. 1). The altitude ranges between 2090 and 2241 m.a.s.l. The name of the monastery is related to the presence of dominant, big and beautiful trees called Albizia gummifera and Albizia schimperiana. In the district, the mean annual rain fall ranges between $1448 \mathrm{~mm}$ and $1808 \mathrm{~mm}$ and the mean annual temperature varies from 11.4 to $25.6^{\circ} \mathrm{C}$. The study area belonged to the Woynadega (mid-temperate midhighland) agroclimatic zone.

The 2007 population and housing census report of Ethiopia showed that the total population of the district was 116,725. The population size of "Aba Libanos kebele" (localized administrative area), which is the immediate vicinity of the study site, was 7830 . From the total 26 "Kebeles" found in the district, this Kebele is the third most crowded area by carrying 233 people per square $\mathrm{km}$. The majority of the population in the district particularly in "Aba Libanos Kebele" depends on

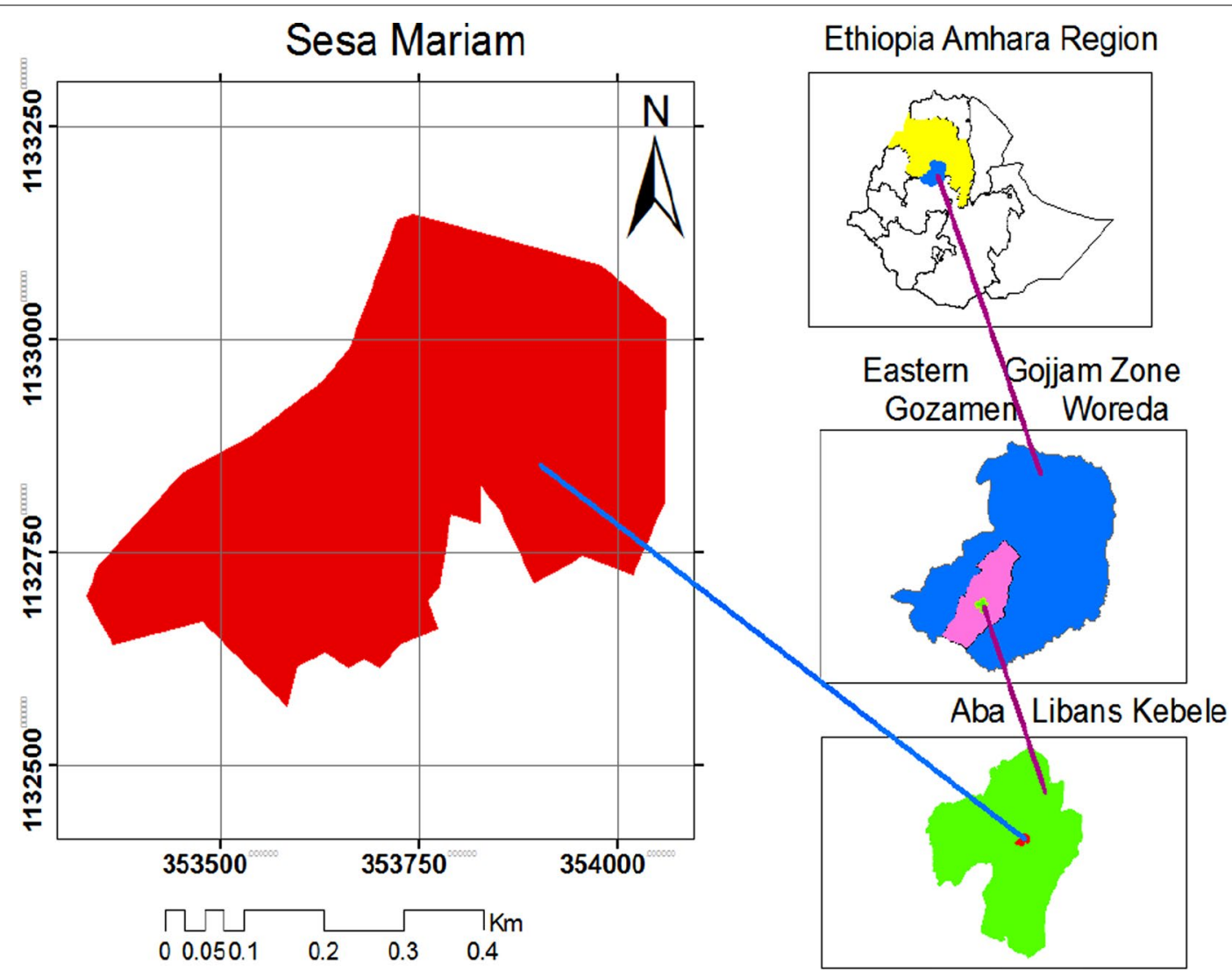

Fig. 1 Map of the study area 
rain-fed agriculture, livestock husbandry and irrigation. In addition to the main crops cultivated in the Kebele, timber, charcoal, fire wood and honey products subsidize the local community's income. Although the monastery lost huge forest lands at different times, dominant and large size tree species like Prunus africana, Albizia gummifera, Albizia schimperiana, Calpurnia aurea, Croton macrostachyus, Juniperus procera, Grewia ferruginea, Celtis africana and Teclea nobilis; shrubs like Carissa spinarum and dominant woody climbers such as Urera hypselodendron and Jasminum abyssinicum are still intact. It also hosts various species of wild animals including mammals, birds, reptiles and amphibians.

\section{Methods}

Four parallel transects were systematically laid across the forest with an interval of $100 \mathrm{~m}$ in the west to east direction. Sample quadrats of $20 \mathrm{~m} \times 20 \mathrm{~m}$ were placed along transects at an interval of $50 \mathrm{~m}$. Thus, for the census of mature plants, a total of 51 main quadrats were considered while for the purpose of seedling and sapling inventory, two sub quadrats of $2 \mathrm{~m} \times 10 \mathrm{~m}$ were laid at the beginning and the end of each main quadrat. The total seedlings and saplings per quadrat were recorded. In each quadrat, all woody and non-woody plant species were identified by their local names, pressed, coded and then grouped as trees, shrubs, herbs and lianas.

In each quadrat, for all plants having diameter at breast height $(\mathrm{DBH}) \geq 2 \mathrm{~cm}$, the circumference measurements were made at breast height (around $1.3 \mathrm{~m}$ ) by using measuring tape following the methods described by Martin 1995 [9]. Since stems born from the same root were considered as a single plant during the census of perennial plants, the diameter of stems branching below or at the breast height was measured separately for each branch and summed.

Individual trees and shrubs with $\mathrm{DBH}<2 \mathrm{~cm}$ and height $<0.5 \mathrm{~m}$ were counted as seedlings while those having $\mathrm{DBH}<2 \mathrm{~cm}$ and height $\geq 0.5 \mathrm{~m}$ were considered as saplings. Perennial plant species that occurred outside the quadrats were also recorded to produce a more complete list of plants but they were not used in subsequent vegetation data analysis. Then, sample plant specimens were properly collected, pressed, dried and carefully identified using the published volumes of Flora of Ethiopia and Eritrea [10-18].

\section{Data analysis}

Matured plant species having DBH $\geq 2 \mathrm{~cm}$ were used in the analysis of vegetation structure. Their abundance, $\mathrm{DBH}$, basal area, density, frequency, and importance value index (IVI) were used in the description of vegetation structure [19]. Species diversity and evenness were measured using the Shannon-Wiener diversity index [19]. To assess the similarity between vegetation samples of the study area and other Ethiopian forests studied with similar methodology, the Sorensen coefficient of similarity index was used [19].

\section{Results and discussion \\ Composition of perennial plants}

A total of 113 plant species belonging to 89 genera and 54 families were recorded in all of the 51 quadrats assessed in SMMF (Additional file 1: Appendix). Of these plant species, 55(48.67\%) were trees, 47 (41.59 \%) were shrubs and $11(9.74 \%)$ were woody climbers. Fabaceae is the most abundant family with 14 species followed by Euphorbiaceae and Rutaceae each with 6 species. Celastraceae was represented by 5 species. Poligonacae, Solanacae, Myrtaceae, and Rosaceae were represented each with 4 species while Oleaceae and Tiliaceae each contributed 3 species. Likewise, the remaining 15 families were represented by 2 species each and 29 families each with 1 species. In addition to this, 7 woody plant species were recorded outside the quadrats of the study area. From the total woody species, about 10 were endemic to Ethiopia, 92 were indigenous and 11 were exotic species. The study area contains some national priority tree species which are commercially important. These are Albizia gummifera, Albizia schimperiana, Croton macrostachyus, Celtis africana, Prunus africana and Juniperus procera.

\section{Species diversity and evenness}

Even though the study area is exposed to some anthropogenic activities such as selective tree cutting, grazing and browsing by domestic animals, and mass destruction in some parts, the overall Shannon-Wiener diversity and evenness indices of matured plant species were 3.81 and 0.85 , respectively. When these values are compared with the findings of others $[7,20]$, they are relatively large. These large values indicate that the plant species are diverse and evenly distributed. Such good diversity and evenness is achieved due to the unlimited protective efforts of the Abbot, Monks in the monastery, and some responsible followers of the religion.

\section{Vegetation structure}

Vegetation structure is a very important tool for orienting management activities and assessing the impact of resource extraction [21]. According to Demel [22], vegetation structure is also important to indicate the regeneration status and the past and the present regeneration patterns of the particular vegetation. To display this; density, frequency, diameter at breast height $(\mathrm{DBH})$, basal area (BA) and important value index (IVI) of matured woody plant species were determined. 
Tree density

The total density of woody plant species in all the 51 sample quadrats of the study area was 2230.39 individuals per hectare. The species with the highest density was Albizia gummifera (9.55 \%) followed by Justicia schimperiana (5.38\%), Carissa spinarum (4.93\%), Teclea nobilis (4.50\%), Croton macrostachyus (3.98\%), Vernonia myriantha (3.90\%), Calpurnia aurea (3.85\%), Grewia ferruginea (3.40\%), Celtis africana (2.83\%), Albizia schimperiana (2.40 \%) and Urera hypselodendron (2.35\%). These species constituted $47.07 \%$ of all stems in all sampling quadrats of the study area. For the 91 selected woody species, the density distribution was as shown in Table 1.

The ratio of tree density $\mathrm{DBH} \geq 10 \mathrm{~cm}$ and $\leq 20 \mathrm{~cm}$ to $\mathrm{DBH}>20 \mathrm{~cm}$ is taken as a measurement of the size class [23]. The ratio at these densities in this monastery was 0.75 . This shows the presence of relatively large differences in abundance between individuals of $\mathrm{DBH} \leq 20 \mathrm{~cm}$ and $\mathrm{DBH}>20 \mathrm{~cm}$. When this value is compared with 13 other natural Afromontane forests found in other parts of Ethiopia, it is very small (Table 2), which confirms the forest is relatively dominated by large plant species.

Table 1 Density of matured woody species of the study area at different $\mathrm{DBH}$ ranges

\begin{tabular}{lll}
\hline DBH $(\mathbf{c m})$ & Density $\left(\mathbf{h a}^{-\mathbf{1}}\right)$ & Percentage \\
\hline $2 \leq \mathrm{DBH}<10$ & 950.00 & 48.45 \\
$10 \leq \mathrm{DBH} \leq 20$ & 431.86 & 22.02 \\
$>20$ & 578.92 & 29.53 \\
Total & 1960.78 & 100 \\
\hline
\end{tabular}

Matured plant species of the study area were classified into five frequency classes based on the percentage frequency values (Fig. 2). The present study revealed a progressive decrease in the percentage of the number of species from the lower to the higher frequency classes. This result confirms the existence of high degree of floristic heterogeneity in the study area.

\section{Diameter at breast height (DBH) distribution}

The distribution of plant species in different DBH classes is shown in Fig. 3. Matured woody plants of the study area were classified into six DBH classes. The first class had the highest distribution of species density per hectare. With the exception of DBH class 5 , the general DBH distribution of trees displayed a decreasing trend from $\mathrm{DBH}$ class 1 to $\mathrm{DBH}$ class 6 . The deviation on DBH class 5 is due to the presence of mature plant species like Albizia gummifera and Albizia schimperiana whose maximum diameter size is at this class range and they have a relatively better protection from the community for commercial value. About $71.4 \%$ of the tree density ha ${ }^{-1}$ was distributed in the first and second $\mathrm{DBH}$ classes but only $1.2 \%$ made the last DBH class. The present study confirmed that not only the existence of a steady decline in density $\mathrm{ha}^{-1}$ of individual trees but also the presence of progressive reduction in the number of species from the lower DBH class to the higher DBH class (Fig. 3).

The DBH distribution pattern of woody plant species indicates the general trend of population dynamics and recruitment status of the species [20]. Thus, the DBH distribution of woody plant species of the study area indicates almost an inverted J-curve. This distribution pattern, according to Tamrat [34] and Alemayehu et al.

Table 2 Comparison of tree densities with DBH between 10 and 20 (a), and $>20 \mathrm{~cm}(\mathrm{~b})$ of the study area with other forests in Ethiopia arranged in increasing order of $a / b$ values

\begin{tabular}{|c|c|c|c|c|c|}
\hline Forests & (a) $10 \mathrm{~cm} \leq \mathrm{DBH} \leq 20 \mathrm{~cm}$ & (b) $\mathrm{DBH}>20 \mathrm{~cm}$ & $a / b$ & Vegetation type & Sources \\
\hline SMMF & 431.86 & 578.92 & 0.75 & Dry Afromontane & Present study \\
\hline Egdu (MAM) & 155 & 197 & 0.79 & Dry Afromontane & {$[24]$} \\
\hline Dodola & 521 & 351 & 1.48 & Dry Afromontane & {$[25]$} \\
\hline Wof washa & 329 & 215 & 1.53 & Dry Afromontane & {$[26]$} \\
\hline Gura Lopho & 333 & 210 & 1.59 & Moist Afromontane & {$[27]$} \\
\hline Alata Bolale & 365 & 219 & 1.67 & Moist Afromontane & {$[28]$} \\
\hline Jimma & 335 & 184 & 1.82 & Moist Afromontane & {$[29]$} \\
\hline Denkoro & 526 & 285 & 1.85 & Dry Afromontane & {$[30]$} \\
\hline Gura Ferda & 500 & 263 & 1.90 & Moist Afromontane & {$[31]$} \\
\hline Dindin & 437 & 219 & 1.99 & Dry Afromontane & {$[6]$} \\
\hline Menna Angetu & 292.59 & 139.8 & 2.09 & Moist Afromontane & {$[32]$} \\
\hline Menagesha & 484 & 208 & 2.33 & Dry Afromontane & {$[26]$} \\
\hline Masha Anderacha & 385.7 & 160.5 & 2.40 & Moist Afromontane & {$[33]$} \\
\hline Chilmo & 638 & 250 & 2.55 & Dry Afromontane & {$[26]$} \\
\hline
\end{tabular}



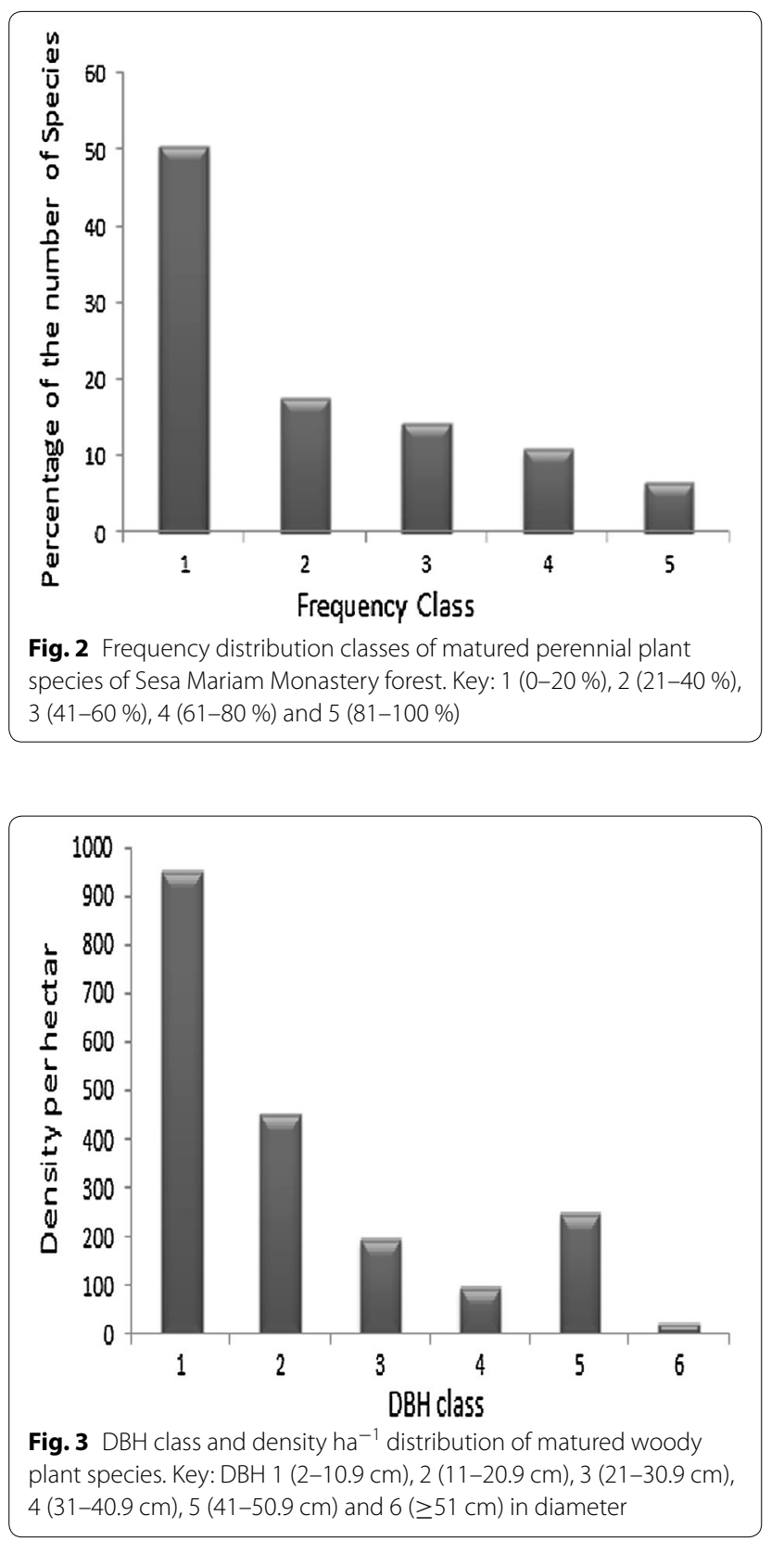

[35], indicates the presence of good regeneration status or stable population structure at the moment in a particular forest.

\section{Basal area (BA)}

The total BA of the study area was $94.81 \mathrm{~m}^{2} \mathrm{ha}^{-1}$ during study period (Table 3). About $66.86 \%$ of the total BA of the vegetation was covered by Albizia gummifera, Croton macrostachyus, Albizia schimperiana, Juniperus procera, and Prunus africana. From these, Albizia gummifera had the biggest contribution to the BA ( $42.63 \%)$ of the forest.
Table 3 DBH classes, density ha ${ }^{-1}, \%$ of density, basal area in $\mathrm{m}^{2} \mathrm{ha}^{-1}$ and \% of basal area of matured woody plants

\begin{tabular}{lllll}
\hline DBH class $(\mathbf{c m})$ & Density $\left(\mathbf{h a}^{\mathbf{- 1}}\right)$ & \% of density & BA $\left(\mathbf{m}^{\mathbf{2}} \mathbf{h a}^{\mathbf{- 1}}\right)$ & $\mathbf{\%}$ of BA \\
\hline $2-10.9$ & 950 & 48.45 & 3.43 & 3.62 \\
$11-20.9$ & 450 & 22.95 & 9.52 & 10.04 \\
$21-30.9$ & 195.09 & 9.95 & 13.99 & 14.76 \\
$31-40.9$ & 97.06 & 4.95 & 11.96 & 12.61 \\
$41-50.9$ & 245.09 & 12.5 & 48.27 & 50.92 \\
$\geq 51$ & 23.53 & 1.2 & 7.63 & 8.05 \\
Total & 1960.78 & 100 & 94.81 & 100 \\
\hline
\end{tabular}

Measurement of BA provides a good measure of the relative importance of the species than simple stem count. So, species with the largest contribution to the BA can be considered as the most important species in the forest. On the other hand, species like Justicia schimperiana, Carissa spinarum, Teclea nobilis, Vernonia myriantha, and Calpurnia aurea contributed less to the BA as compared with their densities' in the forest.

Comparison of the basal area density distribution at different DBH classes showed that about $71.4 \%$ of the plants were distributed in the first and second DBH classes which contributed only $13.66 \%$ of basal area, and about $13.7 \%$ were found in the fifth and sixth DBH classes but their contribution for the basal area was $58.97 \%$ (Table 3). This confirmed that the majority of the basal area was not contributed by the occurrence of more number of individuals but by the presence of some most important plant species of the forest.

The highest $\mathrm{BA}$ value recorded in $\mathrm{DBH}$ class five was due to the higher contribution of Albizia gummifera both in abundance and diameter. When the study area is compared with 15 other monastery and natural forests, it has smaller value than three areas (Table 4). This may be due to the difference in geographical location and the age of the forests but not related with the lack of conservation effort.

\section{Importance value index (IVI)}

Values of IVI are important parameters that reveal the ecological significance of species in a particular ecosystem [36]. Moreover, species with the highest IVI values are the most dominant of the particular vegetation [6]. The analysis of IVI values of the study area revealed that the forest is dominated by few woody plant species like Albizia gummifera. The dominant plant species in the study area (descending order of IVI) were Albizia gummifera, Croton macrostachyus, Albizia schimperiana, Juniperus procera, Calpurnia aurea, Teclea nobilis, Vernonia myriantha, Celtis africana, Justicia schimperiana, Carissa spinarum, Prunus africana, Cordia africana, Urera hypselodendron, 
Table 4 Basal area comparisons of Sesa Mariam monastery forest with 15 other Afromontane monasteries and natural forests found in different parts of the Ethiopia

\begin{tabular}{llll}
\hline Forests & BA $\left(\mathbf{m}^{\mathbf{2}} \mathbf{h a}^{\mathbf{- 1}}\right)$ & Vegetation type & Sources \\
\hline Dodola & 129 & Dry Afromontane & {$[25]$} \\
Tara Gedam & 115.36 & Dry Afromontane & {$[20]$} \\
Wof Washa & 101.80 & Dry Afromontane & {$[26]$} \\
SMMF & 94.81 & Dry Afromontane & Present study \\
Menna Angetu & 94.22 & Moist Afromontane & {$[32]$} \\
Egdu (MAM) & 84.17 & Dry Afromontane & {$[24]$} \\
Masha Anderacha & 81.90 & Moist Afromontane & {$[33]$} \\
Gura Ferda & 69.90 & Moist Afromontane & {$[31]$} \\
Alata Bolale & 53.33 & Moist Afromontane & {$[28]$} \\
Abebaye forest & 49.45 & Dry Afromontane & {$[20]$} \\
Dindin & 49 & Dry Afromontane & {$[6]$} \\
Denkoro & 45 & Dry Afromontane & {$[30]$} \\
Menagesha & 36.10 & Dry Afromontane & {$[26]$} \\
Jimma & 33.30 & Moist Afromontane & {$[29]$} \\
Chilmo & 30.10 & Dry Afromontane & {$[26]$} \\
Gura Lopho & 29.63 & Moist Afromontane & {$[27]$} \\
\hline
\end{tabular}

and Grewia ferruginea. These species contributed about $56 \%$ of the total IVI. The highest IVI of Albizia gummifera was due to its high values of relative frequency, relative dominance and relative density. Important value indices are good indicators for prioritization of species conservation [6].

\section{Regeneration status of plants in Sesa Mariam Monstry Forest}

The composition, distribution, and density of seedlings and saplings indicate the future appearance of a particular forest. Thus, regeneration or recruitment potential of plants is one of the major factors that are useful to assess their conservation status. From the entire 113 plants in the Monastry, a total of 849.52 seedlings ha ${ }^{-1}, 1211.77$ saplings $\mathrm{ha}^{-1}$, and 1960.78 matured plants $\mathrm{ha}^{-1}$ were recorded and identified. The ratio of seedlings and saplings to the matured woody plants was 0.43 and 0.62 , respectively. These results indicated the presence of lower number of seedlings and saplings than the matured ones. This could be due to human intervention, browsing and grazing effects, shade effect, soil erosion and the presence of pests which attack seeds, seedlings and/or saplings. Seedling and sapling abundance analysis confirmed that the regeneration potential of the forest may be in problem unless proper management strategies are soon carried out. Thus, to indicate the conservation priority, woody plant species of the study area were classified into three classes based on their abundance [37]. The first group contained those plant species that do not have seedlings at all and those that are represented by only one seedling. Plant species having seedling abundance $>1$ but $<5$ individuals belonged in the second group and the third group comprised of those having seedling individuals of $\geq 5$. From these, group 1 and group 2 require priority for conservation. Besides, appropriate conservation measures should be given for the third group in order to retain the diversity of woody plant species for the far future.

\section{Phytogeographical comparison}

Sorensen's similarity coefficient index was used to compare woody plant composition of Sesa Mariam Monastery forest with 10 Afromontane forests found in different parts of Ethiopia (Table 5).

Table 5 Comparison of species similarity between Sesa mariam Monastry forest and other different Ethiopian Afromontane forests as calculated by Sorensen's similarity index

\begin{tabular}{|c|c|c|c|c|c|c|c|c|}
\hline Forests & Altitude (m.a.s.I.) & Latitude (N) & Longitude (E) & A & B & $C$ & $\mathrm{Sc}(\%)$ & Sources \\
\hline Sesa Mariam & $2090-2241$ & $10^{\circ} 14^{\prime}-10^{\circ} 14^{\prime}$ & $37^{\circ} 39^{\prime}-37^{\circ} 40^{\prime}$ & - & - & - & - & \\
\hline Gedo & $1300-3060$ & $09^{\circ} 01^{\prime}-09^{\circ} 02^{\prime}$ & $37^{\circ} 16^{\prime}-37^{\circ} 25^{\prime}$ & 61 & 59 & 38 & 55.71 & {$[38]$} \\
\hline Tara Gedam & $2142-2484$ & $12^{\circ} 06^{\prime}-12^{\circ} 07^{\prime}$ & $37^{\circ} 46^{\prime}-37^{\circ} 47^{\prime}$ & 57 & 63 & 42 & 52.05 & {$[20]$} \\
\hline Abebaye & $1921-2072$ & $12^{\circ} 06^{\prime}-12^{\circ} 07^{\prime}$ & $37^{\circ} 46^{\prime}-37^{\circ} 47^{\prime}$ & 50 & 70 & 28 & 50.51 & {$[20]$} \\
\hline Gura Lopho & $2154-2364$ & $09^{\circ} 56^{\prime}-09^{\circ} 57^{\prime}$ & $36^{\circ} 58^{\prime}-37^{\circ} 01^{\prime}$ & 47 & 73 & 51 & 43.12 & {$[27]$} \\
\hline Zegie Peninsula & 1770-1975 & $11^{\circ} 40^{\prime}-11^{\circ} 43^{\prime}$ & $37^{\circ} 19^{\prime}-37^{\circ} 21^{\prime}$ & 50 & 70 & 63 & 42.92 & [39] \\
\hline Adey Amba & $2090-2603$ & $12^{\circ} 31^{\prime}-12^{\circ} 33^{\prime}$ & $37^{\circ} 39^{\prime}-37^{\circ} 41^{\prime}$ & 34 & 86 & 16 & 40.00 & {$[40]$} \\
\hline Sese & $1476-1780$ & $08^{\circ} 28^{\prime}-08^{\circ} 29^{\prime}$ & $35^{\circ} 45^{\prime}-35^{\circ} 50^{\prime}$ & 43 & 77 & 64 & 37.89 & {$[41]$} \\
\hline Mana-Angetu & $1533-2431$ & $06^{\circ} 10^{\prime}-06^{\circ} 31^{\prime}$ & $39^{\circ} 30^{\prime}-39^{\circ} 45^{\prime}$ & 43 & 77 & 106 & 31.97 & {$[32]$} \\
\hline Gurra-Ferda & 1650-2055 & $06^{\circ} 45^{\prime}-07^{\circ} 08^{\prime}$ & $35^{\circ} 00^{\prime}-35^{\circ} 15^{\prime}$ & 29 & 91 & 37 & 31.18 & {$[31]$} \\
\hline Denkoro & $2300-3400$ & $10^{\circ} 35^{\prime}-11^{\circ} 15^{\prime}$ & $38^{\circ} 30^{\prime}-39^{\circ} 07^{\prime}$ & 27 & 93 & 38 & 29.19 & {$[30]$} \\
\hline
\end{tabular}

Total number of plant species in Sesa mariam Forest (SMMF) $=113$

Sc (Sorensen's similarity coefficient) $=2 \mathrm{~A} / 2 \mathrm{~A}+\mathrm{B}+\mathrm{C}$

$A$ plant species common to SMMF and the forest in comparison, $B$ plant species found only in SMMF, $C$ plant species found only in the forest in comparison with SMMF 
Based on the information from Table 5, the study area shared the highest similarity with Gedo Dry Afromontane forest (55.71 \%) followed by Tara Gedam (52.05\%) and Abebaye forest (50.51\%). This might be due to similarities in temperature, rain fall and altitudinal ranges.

\section{Conclusion}

It is obvious that the monastery has lost extensive forestlands at various times in the past. However, currently the church community has recognized the importance of the remaining forest to its existence and the ecosystem. Hence, it has made the survival of the diversified indigenous plants possible. Regardless of such positive attitude from the church community and the relative conservation efforts made, seedling and sapling abundance analysis revealed 71 out of 113 woody plant species to be represented by either one or no seedlings at all. This shows that the regeneration potential of the forest is declining and intervention measures are needed. Grazing by livestock and farm land expansion are the major threats to the forest resources, which demands a necessity for more concerted effort towards protection of the church forest.

\section{Additional file}

Additional file 1: Appendix. List of plant species in Sesa Mariam monastery forest showing the total basal area in $\mathrm{m}^{2} \mathrm{ha}^{-1}\left(\mathrm{BA}\right.$ in $\left.\mathrm{M}^{2} \mathrm{Ha}^{-1}\right)$, density $\mathrm{ha}^{-1}$, relative frequency (RF), relative density (RD), relative dominance (RDo), importance value index (IVI), and percent of importance value index (\%IVI) in descending order of priority classes (PC).

\section{Abbreviations}

SMMF: Sesa Mariam Monastery Forest; USAID: United States Agency for International Development; EOTC: Ethiopian Orthodox Tewahdo Church; DBH: Diameter at breast height; BA: Basal area; IVI: Importance value index; SC: Sorenson's similarity Coefficient.

\section{Authors' contributions \\ BWM proposed the research topic and did the actual experimental survey. BAT endorsed the topic, participated on the study design, supervised the data collection and wrote the manuscript for publication. BBT was involved in the identification of plant specimens. All authors read and approved the final manuscript.}

\section{Author details}

${ }^{1}$ Department of Biology, Debremarkos College of Teacher Education, Debre Marqos, Ethiopia. ${ }^{2}$ Department of Biology, Bahir Dar University, Bahir Dar, Ethiopia. ${ }^{3}$ Gullelie Botanical Garden, Addis Ababa University, Addis Ababa, Ethiopia.

\section{Acknowledgements}

The authors would like to thank the monastery community especially the Abbot for providing the necessary information with respect to the vernacular names of the plants and allowing access to the monastery. The transport cost to the study site was covered by Bahir Dar University.

\section{Competing interests}

The authors declare that they have no competing interest.
Received: 23 February 2015 Accepted: 5 October 2015

Published online: 30 October 2015

\section{References}

1. Convention on Biological Diversity (CBD). CBD News: forest and aquatic plants genetic resources. Addis Ababa: Institute of biodiversity conservation; 2008.

2. Tewoldeberhan G. Plant genetic resources of Ethiopia. In: Engles JMM, Hawkers JG, Worede M, editors. Diversity of Ethiopian Flora. Cambridge: Cambridge University press; 1991.

3. World Conservation Monitoring Center (WCMC). Global biodiversity: status of the earth's living resource. London: Champion and Hall; 1992.

4. USAID/Ethiopia (United States Agency for International Development/ Ethiopia). Ethiopian Biodiversity and Tropical Forests 118/119 Assessment. 2008. http://pdf.usaid.gov/pdf_docs/PNADM939.pdf. Accessed February 2013

5. Million B. Forestry outlook study in Africa. Regional, sub Regional and Countries Report, opportunities and challenges towards 2020; FAO forestry paper No. 141. Synthesis Africa Forests View to 2020. Rome, Italy; 2001.

6. Simon S, Girma B. Composition, structure and regeneration status of woody species in Dindin national forest, souse east Ethiopia: an implication for conservation. Ethiop J Biol Sci. 2004;3(1):31-48.

7. Alemayehu W. Opportunities, constraints and prospects of the Ethiopian Orthodex Tewahido Churches in south Gondar, northern Ethiopia. MSc. Thesis: Swedish University of Agricultural Sciences; 2002.

8. Conservation International. http://www.conservation.org. Accessed February 2012.

9. Martin GJ. Ethno botany: a method manual. London: Chapman and Hall; 1995.

10. Edwards S, Demissew S, Hadberg I, editors. Flora of Ethiopia and Eritrea, vol. 5: Gentianaceae to Cyclocheilaceae. Addis Ababa: The National Herbarium and Uppsala: The Department of Systematic Botany; 2006.

11. Edwards S, Mesfin T, Hadberg I, editors. Flora of Ethiopia and Eritrea, vol. 2 part 2: Canellaceae to Euphorbiaceae. Addis Ababa: The Nationa Herbarium and Uppsala:The Department of Systematic Botany; 1995.

12. Edwards S, Mesfin T, Sebsbie D, Hadberg I, editors. Flora of Ethiopia and Eritrea, vol. 2, part 1: Magnoliaceae to Flacourtiaceae. Addis Ababa: The National Herbarium and Uppsala: The Department of Systematic Botany; 2000.

13. Hedberg I, Edwards S, editors. Flora of Ethiopia and Eritrea, vol. 3: Pittosporaceae to Araliaceae. Addis Ababa: The National Herbarium and Uppsala:The Department of Systematic botany; 1989.

14. Hedberg I, Edwards S, editors. Flora of Ethiopia and Eritrea, vol. 7: Poaceae (Gramineae). Addis Ababa:The National Herbarium and Uppsala: The Department of Systematic Botany; 1995.

15. Hedberg I, Edwards S, Nemomissa S, editors. Flora of Ethiopia and Eritrea, vol.4, Part 1: Apiaceae to Dipsacaceae. Addis Ababa:The National Herbarium and Uppsala: The Department of Systematic Botany; 2003.

16. Hedberg I, Fris I, Edwards S, editors. Flora of Ethiopia and Eritrea, vol.4, part 2: Asteraceae (Compositae). Addis Ababa: The National Herbarium and Uppsala: The Department of Systematic Botany; 2004.

17. Hedberg I, Kelbessa E, Edwards S, Nemomissa S, Demissew S, Persson E, editors. Flora of Ethiopia and Eritrea, vol.6: Hydrocharitaceae to Arecaceae. Addis Ababa: The National Herbarium and Uppsala: The Department of Systematic Botany; 1997.

18. Azene B. Useful trees and shrubs for Ethiopia, identification, propagation and management for 17 Agroclimatic zones. In: Tengnas B, Ensermu K, Sebsebe D, Maundu P, editors. Technical manual. Kenya: World Agroforestry Centre Nairobi; 2007.

19. Kent $M$, Coker P. Vegetation description and analysis. a practical approach. New York: Wiley; 1992.

20. Haileab Z, Demel T, Ensermu K. Diversity and regeneration status of woody species in Tara Gedam and Abebaye forests, northwestern Ethiopia. J Forestry Res. 2011;22(3):315-28. 
21. Peters CM. The ecology and management of non-timber forest resources. World bank technical paper No. 322; 1996.

22. Demel T. Seed ecology and regeneration in the dry afromontane forests of Ethiopia. Ph. D. Thesis, Swedish University of Agricultural Sciences, Umea; 1996.

23. Grubb PJ, Lloyd JR, Pennington JD, Whitmore JC. A comparison of Montane and lowland rain forests in Ecuador. The forest structure, physiognomy and floristics. J Ecol. 1963;51:567-601.

24. Abiyou T. Floristic composition and structure of vegetations in Menagesha Ambamariam forest in central highlands of Ethiopia. M.Sc. Thesis, Addis Ababa University; 2008.

25. Kitessa H. Floristic composition and structure of the Dodolla forest, Bale zone, Oromia Regional State. M.Sc. Thesis, Addis Ababa University; 2003.

26. Tamrat B. Vegetation ecology of remnant afromontane forests of the central plateau of Shewa, Ethiopia. Acta Phytogeogr Suecica. 1993;79:1-59.

27. Lemessa K. Floristic composition and structure of Gura-Lopho Moist Afromontane Forest, Horo-Guduru Wollega Zone, Oromia National Regional State, West Ethiopia. M.Sc. Thesis, Addis Ababa University; 2010

28. Woldeyohannes E. Floristic analysis of Aleta-Bolaleforest in Gudeya Bila Woreda, East Wollega Zone. M.Sc. Thesis, Addis Ababa University; 2008.

29. Fufa K. Remnant vegetation and population structure of woody species of Jima Forest, western Ethiopia. M.Sc. Thesis. Addis Ababa University; 2008.

30. Abate A. A floristic composition and structural analysis of Denkoro Forest, South Wello. M.Sc. Thesis, Addis Ababa University; 2003.

31. Dereje D. Floristic composition and ecological study of Bibita Forest (Gura Ferda), South west Ethiopia. M.Sc. Thesis. Addis Ababa University; 2006.
32. Ermias L, Ensermu K, Tamirat B, Haile Y. Plant species Composition and structure of Mana-Angetu moist montane forest, southeastern Ethiopia. J East Afr Nat Hist. 2008;97(2):165-185.

33. Kumlachew $Y$, Taye $B$. The woody species composition and structure of Masha-Anderacha forest, southwestern Ethiopia. Ethiop J Biol Sci. 2003;2(1):31-48.

34. Tamrat B. Studies on Remnant Afromontane Forests on Central Plateau of Shewa. Ph.D. Thesis. Uppsala University, Sweden; 1994.

35. Alemayehu W, Demel T, Powell N. Church forests in north Gondar Administrative Zone, northern Ethiopia. For Trees Livelihoods. 2005;15:349-73.

36. Lamprecht H. Silviculture in the tropics: tropical forest ecosystems and their tree species possibilities and methods for their long term utilization. Eschborn: Federal Republic of Germany; 1989.

37. Sultan M, Berhanu AT. Floristic composition and structure of Yegof Mountain Forest, South Wollo, Ethiopia. Ethiop J Sci Technol. 2013;6(1):33-45.

38. Birhanu K. Floristic composition and structural analysis of Gedo dry evergreen montane forest, west Shewa zone, Central Ethiopia. M.Sc. Thesis, Addis Ababa University; 2010.

39. Alemnew A, Demel T, Yonas Y, Edwards S. Diversity and regeneration status of woody plants on the peninsula of Zegie, north western Ethiopia. Trop Ecol. 2007;48:37-49.

40. Wondie M. Woody species diversity and regeneration status of Aday Amba enclosed forest in northwest Ethiopia. M.Sc. Thesis, Bahir Dar University; 2011.

41. Shiferaw B. Floristic composition, structure and regeneration status of woody plant species of Sese Forest, Oromia National Regional State, South East Ethiopia. M.Sc. Thesis, Addis Ababa University; 2010.

\section{Submit your next manuscript to BioMed Central and take full advantage of:}

- Convenient online submission

- Thorough peer review

- No space constraints or color figure charges

- Immediate publication on acceptance

- Inclusion in PubMed, CAS, Scopus and Google Scholar

- Research which is freely available for redistribution

Submit your manuscript at

www.biomedcentral.com/submit

C BioMed Central 